$\mathrm{JRF}$

19,5

414

Received 8 February 2017

Revised 24 July 2017

31 December 2017

1 March 2018

Accepted 10 April 2018

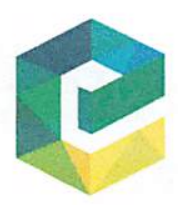

The Journal of Risk Finance Vol. 19 No. 5,2018 pp. $414-436$

E Emerald Publishing Limited 1526-5943

DOI $10.1108 /$ JRF-02-2017-0033

\section{Shadow credit in the middle market: the decade after the financial collapse}

\author{
Craig Anthony Zabala \\ The Concorde Group Inc, New York, New York, USA and \\ Max Planck Institute for the Study of Societies, Cologne, Germany and \\ Institute for Research on Labor and Employment, University of California, \\ Los Angeles, California, USA, and \\ Jeremy Marc Josse \\ Department of Financial Institutions Group and Compliance, \\ Brock Capital Group LLC, New York, New York, USA
}

\begin{abstract}
Purpose - The purpose of this paper is to review the continued development of the "shadow banking" market in the USA, namely, lending to the private middle market, defined as financings of $\$ 5-100 \mathrm{~m}$ to nonpublic, unrated operating entities or pools of assets with not more than $\$ 50 \mathrm{~m}$ in earnings before interest, taxes, depreciation and amortization.

Design/methodology/approach - The analysis includes a continued review of an innovative segment of the financial markets and primary evidence from direct participation in four actual cases of private, nonbank lending between 2013 and 2015 and theoretical observations around that data.

Findings - Although there have been considerable challenges, historically, in providing credit for small and mid-sized businesses in the USA, the authors show further evidence that private middle market capital is growing (post credit crisis) at a dramatic pace, in part because of excessive constraints placed on the regulated depositary institutions. The authors also explain the nature of the shadow banking innovation and how it is intrinsically linked to "arbitraging" often excessively restrictive banking regulation. The growing US shadow banking market, while providing an important service to middle market companies, may pose a new systemic risk post 2007-2008 credit crisis in the USA.

Research limitations/implications - Any generalization is limited because of the difficulty in extrapolating from a small number of specific case studies and the absence of adequate survey data for the US capital markets and the limited examples examined.

Practical implications - This research calls for additional case studies, including participant observation research that offers a unique close-up view of financial behavior that is often beyond the view of regulators and the public. Data obtained may be useful in providing a deeper, more timely understanding of credit market behavior and contribute to efforts at formal financial modeling as well as the development of practical regulatory regimes.
\end{abstract}

Social implications - The shadow credit market is a key source of funding for the global financial system, thus contributing to job creation and economic growth. The authors demonstrate the value of financial innovations and show that shadow credit fills a void left by depository financial institutions,

The authors want to thank Gerald L. Brodsky for his critical review and insightful comments at various stages of this research, and Richard J. Kelly for his excellent research assistance. Mr Kelly passed away due to amyotrophic lateral sclerosis in August 2017. Finally, they thank the anonymous reviewers for their suggestions and criticisms that improved this paper immeasurably. Co-author Jeremy Josse passed away unexpectedly on June 12, 2018; Dr Zabala wishes to note that Mr Josse's contributions to this research paper were innumerable. 
shifting much of the risk from the public to investors. This research increases transparency in the operation of this market, which is extremely important for the industry, the government and the public. The authors offer a modest attempt at understanding credit behavior to avoid a repeat of the 2007/2008 financial crisis.

Originality/value - Direct participation is unique to the firms studied. Value is in developing a general framework to analyze an emerging credit market in advanced economies.

Keywords Credit, Collateral, Underwriting, Risk, Shadow banking, Financial innovation

Paper type Literature review

\section{Introduction}

\subsection{Shadow banking system and shadow credit market}

Unlike regulated real banks, who fund themselves with insured deposits, backstopped by access to the Fed's discount window, unregulated shadow banks fund themselves with un-insured commercial paper, which may or may not be backstopped by liquidity lines from real banks. Thus, the shadow banking system is particularly vulnerable to runs - commercial paper investors refusing to re-up when their paper matures, leaving the shadow banks with a liquidity crisis - a need to tap their back-up lines of credit with real banks and/or to liquidate assets at fire sale prices.

Paul A. McCulley, PIMCO, Jackson Hole, WY, September 2007.

McCulley coined the expression shadow banking system (SBS). The shadow credit market (SCM)[1] comprises non-depository (non-bank) credit providers to small- and mid-sized businesses without access to bank credit. The Financial Stability Board (2011, p. 1) describes the SCM as "credit intermediation involving entities and activities outside the regular banking system". The concern, of course, is that opaque side vehicles created by depository institutions and insurance companies eliminated depositor protections and enabled large sums of capital to fuel the scale and scope of an opaque and poorly understood SCM. Thus, systemic risk. But it was Fed Governor Edward M. Gramlich (Philadelphia) who, in December 2000, first raised the alarm of dark lending practices, severe lack of regulatory oversight and systemic risk in subprime mortgages (Gramlich, 2000, 2007; Sullivan, 2007). Roubini and Setser $(2004 a, b)$ referred to the unsustainability of the global credit markets. Stiglitz (2006) analyzed excessive debt of private companies and opaque structures. More recently, the political economist, Wolfgang Streeck (2014), analyzed the unsustainability of the government debt markets, which will dramatically affect private credit markets.

In the post-2008 Dodd-Frank Wall Street Reform and Consumer Protection Act era (Dodd-Frank), shadow credit refers primarily to private (non-public) financial services firms that operate outside the banking regulatory regimes. The absence of regulatory filings, limited oversight and different regulators enable these firms to operate in the shadows of the capital markets, which exacerbates the challenge regulatory agencies face in gathering industry data on leverage and credit risk in this capital market segment. This is a characteristic of the US regulatory regime, in which regulation is handled by separate, sometimes overlapping and competing, government and quasi-government (e.g. selfregulatory organizations, "SROs") agencies. However, not all of the SCM is opaque, as public firms have quarterly and annual filing requirements.

For example, business development companies (BDCs) comprise a part of the SCM with approximately $\$ 35 \mathrm{bn}$ of assets under management. A BDC is a closed-end fund that is not technically registered under the Investment Company Act of 1940 (the "1940 Act") but elects to be governed under the 1940 Act and to be regulated by the US Securities and Exchange 
$\mathrm{JRF}$

19,5

416

Commission (the "SEC"), including independence requirements for board members, valuation requirements and restrictions on investments (e.g. qualifying assets). (This includes private BDCs, which must maintain their quarterly and annual filings even though their shares are not traded on a stock exchange.) A BDC operates like a typical 1940 Act closed-end fund, but, unlike a 1940 Act fund, must invest its assets according to specific criteria set out in the 1940 Act. Moreover, BDCs have severe leverage restrictions and are required to offer "significant managerial assistance" to eligible portfolio companies. Camp and Ponchione (2013) wrote that:

Goldman Sachs' recent filing with the Securities and Exchange Commission (SEC) to launch a "business development company," or BDC, should be of interest to financial services companies, particularly banking institutions structuring and restructuring their operations and product offerings to comply with the Volcker Rule's prohibitions on investing in and sponsoring "covered funds."

In addition, the emerging "FinTech" sector represents another unique set of regulatory challenges within the SCM sector.

Zabala and Josse (2014) described the growth of the SCM from the turn of the century. This paper extends the discussion. In this paper, we provide additional evidence that the private, non-bank credit markets are providing solutions to a range of different funding challenges across the USA, funding requirements that are not necessarily being met by the mainstream community and large banks. (A similar argument may be made in the international financing area as well.) Critically, we attempt to explain the SBS innovation and why it is such a material part of the US middle market capital markets. We also note that the ongoing growth of the US SBS (a wholesale-funded, non-government-insured market) could itself be creating a new systemic risk in the US credit system.

This paper extends our previous research in the US shadow banking sector providing detailed analysis and additional case studies of recent private, mid-market (non-bank) commercial credit transactions (Zabala and Josse, 2013, 2014).

\subsection{The state of the research}

The Economist has given extensive coverage to the SCM (A.A.K., 2016). Marshall (2014) similarly describes the SCM operating before Dodd-Frank implemented stringent restrictions that led the banks to close their trading desks and lay off staff.

Górnicka (2016, p. 118) studies how shadow banks augment banks, and citing Pozsar et al. (2010):

Banks responded to growing competition by involving in "regulatory arbitrage": setting up specialized non-bank entities and shifting many of their activities there. In this way, banks could carry out financial intermediation without having to comply with costly capital and other requirements.

Off-balance sheet special-purpose vehicles (SPVs) were designed to deploy capital in ways noncompliant with bank regulations to avoid costly capital requirements and to increase return on capital (Górnicka, 2016, p. 128). The Dodd-Frank Act was implemented, in part, to eliminate SPVs and attendant systemic risk. However, other financial intermediaries (OFIs) away from the traditional depositary institutions have arisen to take significant advantage of this regulatory arbitrage opportunity.

Much of the research to date has focused on bank regulation (Adrian and Shin, 2009; Adrian et al., 2012; Krugman, 2009; Stiglitz, 2010; Gorton, 2010; O'Sullivan and Kinsella, 2012; Camp and Ponchione, 2013; Sinha, 2013; Guillaume, 2015; Helgadóttir, 2016). The 
dramatic growth in the SCM over the past decade has led some to question whether this can be called shadow banking any longer, though this view is exaggerated (Baber, 2013). A macroeconomic literature has emerged that models the SCM (Moreira and Savov, 2014; Moe, 2015; Sunderam, 2015). (Gennaioli et al., 2013). Money market funds (MMFs) have attracted considerable attention because of retail investor participation (Chernenko and Sunderam, 2014; Cipriani et al., 2013). Bengtsson (2016) examined investment fund exposure. This research primarily focuses on systemic risk in depository banks, insurance companies and large credit and hedge funds susceptible to systemic risk largely by looking backward at the pre-2007/2008 period.

Studies of China's banking sector largely conclude that its domestic SCM mirrors the US and European banking practices and opaque lending structures outside regulatory control in the pre-2007 period and, thus, significant downside risk that may destabilize the global economy (The Economist, 2006, 2014, 2016a, 2016b, 2016c; Barth et al., 2015; Li et al., 2014; Li, 2014; Lu et al., 2014).

The financialization literature argues that state-driven sponsorship of innovations in financial instruments and oversight regimes in the pre-2007 period explains the run up to 2007/2008 (Krippner, 2005, 2009). Kessler and Wilhelm (2013) used financialization theory to study the SCM. Buchanan $(2015,2016)$ extended the financialization school by studying the historical development and flawed implementation of securitization, placing it within a macro theoretical framework. She considered the ethics of risk transfer at the heart of the global credit markets. Buchanan's focus on investment suitability and risk management is important. Stein (2010) looked explicitly at securitization risk within the SCM. Josse (2015) and Knoll (2004) both showed that so-called financialization predates industrial capitalism, with Josse looking at pre-capitalist notions of currency, investment, risk and derivatives and Knoll focused on pre-capitalist regulatory arbitrage. We argue that much financial innovation flows from the bottom up in the financial markets well ahead of government initiatives and mandates.

In contrast, we have offered previously and continue to offer herein an analysis of the SBS and SCM per se.

Our analysis provides empirical evidence of the characteristics and growing depth of the US SBS in the past few years. In furtherance of our previous paper, we provide additional evidence that the private, non-bank credit markets are providing solutions to a range of differing funding challenges across the USA, funding requirements that are apparently not being met by the mainstream community and large commercial banks. In this paper, we will focus on that part of the SCM that is emergent and largely independent of the depository institutions, which are the primary focus of much of the research to date. We emphasize the resilience of capital to find investment opportunities during and following periods of economic tumult. Our argument is that post-crisis, private capital, as constrained by slow economic growth, and as exacerbated by the Federal Reserve Board's low-interest rate policies, and the Dodd-Frank regulatory framework, moved to alternative investments. This portfolio shift resulted in significant SCM growth and interesting, non-systemic innovations. We extend our data analysis to 2014, and in a few series through late 2015, and introduce a number of additional cases exemplifying recent financial innovations in the constantly evolving SBS with which we had direct experience. This should offer new insights to the SCM literature and suggest future research.

\section{Shadow credit market growth and segmental features}

We first chart the growth in the entire SBS in recent years. Concurrent with rapid developments in financial innovation and technology in the USA, as well as a favorable
Shadow credit in the middle market 
$\mathrm{JRF}$

19,5

418

financing environment, the global shadow banking system (the "GSBS") experienced substantial expansion in the 2002-2014 period, increasing in size from $\$ 30.0 \mathrm{tn}$ in 2002 to $\$ 79.8$ tn in 2014. According to the Financial Stability Board (the "FSB"), shadow banking tends to take off, in particular, when strict banking regulations are in place, when real interest rates and yield spreads are low and investors search for higher returns and when there is a large institutional demand for assets, for example from insurance companies and pension funds. Hence, the current environment in advanced economies seems conducive to further growth of shadow banking.

The FSB, in compiling its data sets, has identified and collected data for the sectors of financial intermediaries shown.

Financial institutions

(1) Central banks

(2) Banks

- Banks'assets to OFI

- Banks' liabilities to OFI

(3) Insurance companies

(4) Pension funds

(5) Public financial institutions

(6) OFI

- Money market funds

- Finance companies

- Structured finance vehicles

- Hedge funds

- Other investment funds

- Brokers dealers

- Real estate investment trusts and funds

- Trust companies

- Others (identified)

- Others (unidentified)

(7) Financial auxiliaries

Notes: Financial institutions include all sectors listed below each heading. Items in italics are sector-specific.

Source: Financial Stability Board (2014)

According to the FSB, banks refer to the broader category of deposit-taking institutions as measured by financial assets when available, otherwise total assets. The data are aggregated across 20 jurisdictions and the euro area In addition to the euro area, the 20 jurisdictions are Argentina, Australia, Brazil, Canada, Switzerland, Chile, China, the UK, Hong Kong, Indonesia, India, Japan, Korea, Mexico, Russia, Saudi Arabia, Singapore, Turkey, the USA and South Africa. In case of missing data in a time series, values were not interpolated or extrapolated. Some aggregated series have breaks and an increase in an aggregated series may be the result of improvements in reporting of a sub-sector over time rather than an increase in the volume of financial assets. The banks' assets to OFI and banks' liabilities to OFI figures are not adjusted for banks' assets and liabilities to OFI that are consolidated into banking groups. In addition, all figures were converted to US dollars at the appropriate year-end. 
However, the data that have been illustrated in this paper could be significantly muted because of the inability of the FSB to capture the full impact of the hedge fund sector on the GSBS. This sector is significantly underestimated primarily because of two factors. First, offshore financial centers, where most hedge funds are domiciled, are not included in the current scope of the exercise. Second, the flow of funds statistics are not granular enough in many jurisdictions to allow a separation between hedge funds and other sectors. The FSB plans to address the hedge fund sector in ensuing periods.

Figure 1 indicates the growth of assets of non-bank financial intermediaries since 2002 for 20 jurisdictions and the euro area, which represent 80 per cent of global GDP and 90 per cent of global financial assets. Notice the significant expansion during the pre-crisis period from 2002 to 2007 , which grew 122.3 per cent from US $\$ 30.0$ tn to US $\$ 66.7 \mathrm{tn}$, and the resumption of growth from 2009 to 2013, which increased such assets another 24.5 per cent from US\$64.1tn to US\$79.8tn in 2014. The GSBS, as a percentage of GDP, grew from 94.8 per cent in 2002 to 129.7 per cent in 2007, representing 34.9 per cent appreciation. Following the financial crisis of 2007-2008, and a decline to 116.7 per cent in 2008, growth resumed in 2009, from 121.0 per cent to 127.6 per cent in 2014, not back to the pre-crisis levels, but still an important ingredient in the world economy.

Figure 2 shows the assets of all financial intermediaries, both bank and non-bank participants, for 20 jurisdictions and the euro area, since 2002. The GSBS sector continues to show continued growth versus other non-bank financial intermediaries and remains in second place relative to the banking industry. The GSBS now accounts for 25.3 per cent of total banking assets in 2014. This continues to illustrate the importance of the GSBS.

Although the USA remains the largest country in the shadow banking market, other countries, such as Argentina, Australia, Brazil, Chile, the euro area, Hong Kong, Ireland, Korea, The Netherlands, Russia, Singapore, Spain, Switzerland and the UK, are showing far more rapid growth rates than that of the USA, although those countries are growing from smaller bases (FSB, 2014, 2015).

On the next page, in Figure 3, the sub-sectors of the GSBS are shown by their respective percentages of the market for 2014. Other investment funds, including equity funds, bond funds and MMFs, continue to dominate the sub-sectors of the GSBS, accounting for 47.2 per cent of the total. Hedge funds continue to be misrepresented and understated in the GSBS figures due to the FBS's inability to capture this data.

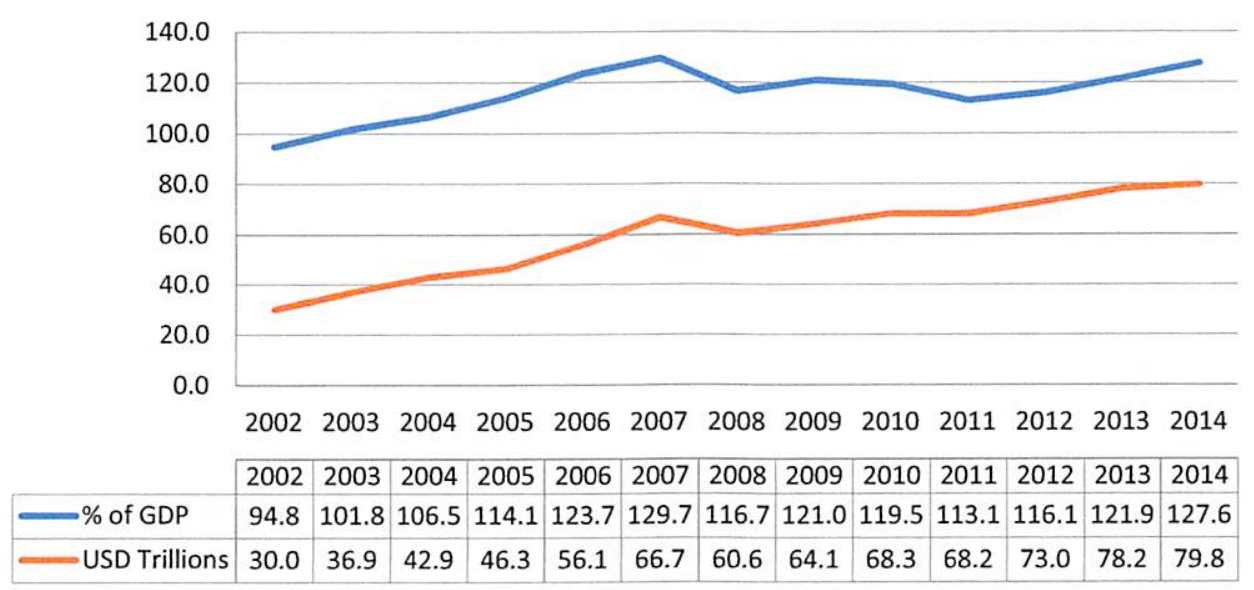

Source: Financial Stability Board $(2014,2015)$
Shadow credit in the middle market

419
Figure 1. Assets of non-bank financial intermediaries since 2002, 20 jurisdictions and euro area (in US\$ trillions) 
JRF

19,5

Figure 2.

Total financial assets of financial intermediaries, 20 jurisdictions and euro area (in US\$ trillions)

Figure 3.

Sub-sectors of nonbank financial intermediaries for 20 jurisdictions and the euro area for 2014

\subsection{Credit exposure and leverage risk}

Table I from the FSB shows the assets and liabilities of banks to OFIs. Notice the considerable growth in the assets of OFI and banks since 2002, but the growth in banks' assets to OFI is nearly matched by their liability growth. The banks' assets to OFI are loans. Their liabilities comprise deposits and notes that the OFI has placed with the banks. Loans are nearly covered by liabilities. As such, the banks, to date, are not overexposed to the OFI.

As previously mentioned, the USA has the largest shadow banking sector in the world, totaling $\$ 25.7 \mathrm{tn}$ in 2014, representing nearly one-third of the GSBS sector in that year as shown in Figure 4. In fact, the US market returned in 2013 to the levels it had achieved prior to the 2007-2008 financial crisis. We anticipate growth to continue owing

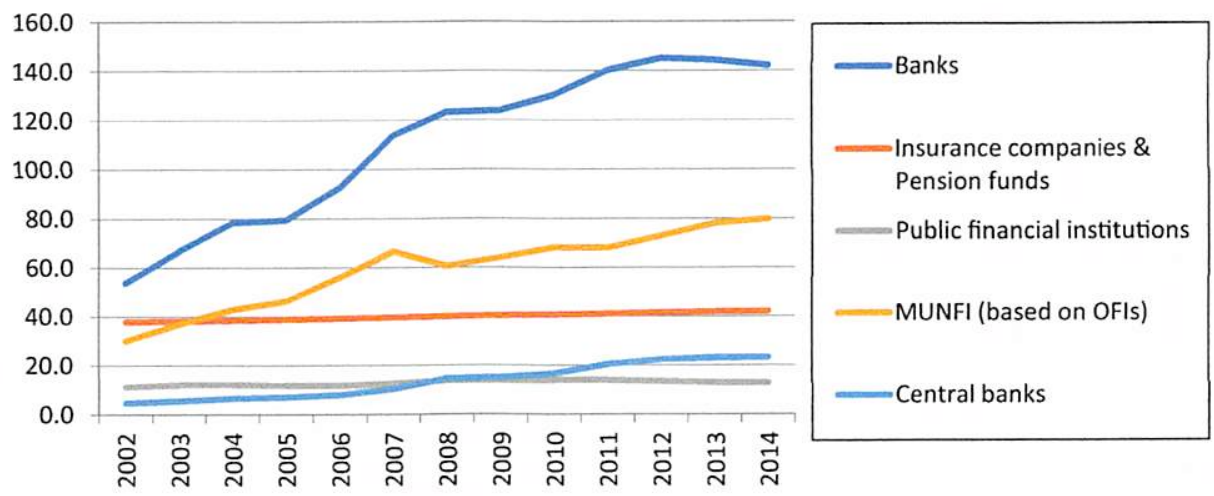

Source: Financial Stability Board $(2014,2015)$

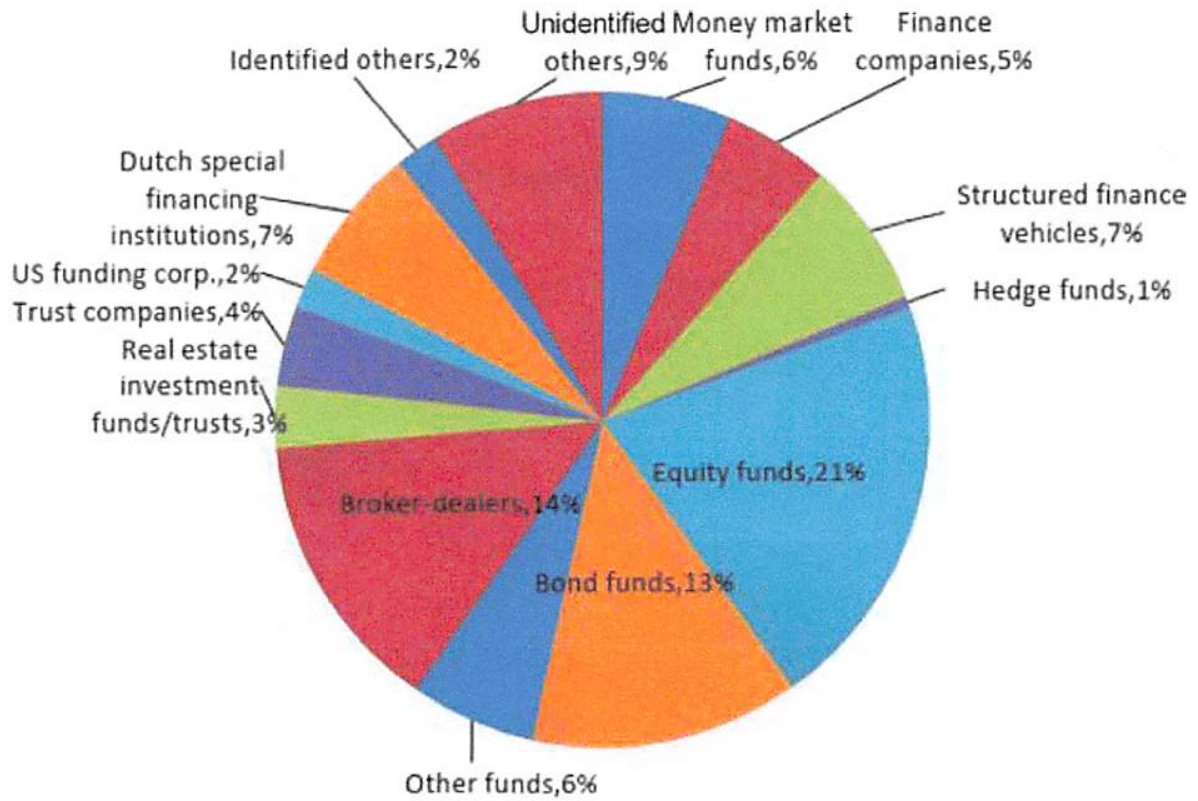

Source: Financial Stability Board $(2014,2015)$ 


\begin{tabular}{lrccr}
\hline & Banks & Banks' assets to OFIs & Banks' liabilities to OFIs & OFIs \\
\hline 2002 & 53.8 & 1.4 & 1.6 & 30.0 \\
2003 & 67.0 & 1.9 & 2.0 & 36.9 \\
2004 & 78.5 & 2.4 & 2.5 & 42.9 \\
2005 & 79.5 & 2.4 & 2.8 & 46.3 \\
2006 & 92.7 & 3.5 & 3.8 & 56.1 \\
2007 & 113.8 & 5.5 & 5.6 & 66.7 \\
2008 & 123.3 & 8.3 & 8.0 & 60.6 \\
2009 & 124.0 & 7.5 & 7.8 & 64.1 \\
2010 & 130.3 & 7.3 & 8.2 & 68.3 \\
2011 & 140.2 & 8.1 & 8.4 & 68.2 \\
2012 & 145.2 & 8.0 & 8.1 & 73.0 \\
2013 & 144.4 & 7.2 & 7.6 & 78.2 \\
2014 & 142.2 & 6.4 & 7.0 & 79.8
\end{tabular}

Shadow credit in the middle market 421

Table I. Assets of financial institutions (in US\$ trillion), 20 jurisdictions and euro area $(20+\mathrm{EA}$ group)

Source: Financial Stability Board $(2014,2015)$

Figure 4. Assets of US nonbank financial intermediaries in US\$ trillions Since 2002

Source: Financial Stability Board $(2014,2015)$

to the current bank regulatory environment, which preempts commercial banks' participation.

\subsection{US leveraged loan market}

In general, because of regulatory regime changes such as Dodd-Frank and new capital requirements, the leveraged loan market in recent years has trended away from depository financial institutions (except for revolving bank debt) due either to risk, structure, lack of liquidity or a combination of all three. Hence our interest in this market, which has been trending toward the SBS in recent years.

As shown in Figure 5, new originations of leveraged loans in the USA totaled $\$ 528.1 \mathrm{bn}$ for FY 2014, down 13.0 per cent from $\$ 606.7 \mathrm{bn}$ in FY 2013. Through late 2015, new originations totaled $\$ 410.9 \mathrm{bn}$, off $\$ 89.6 \mathrm{bn}$ from the total of $\$ 500.5 \mathrm{bn}$ for the comparable period in 2014 . Although originations have been trending downward since the recent peak in 2013, the high level of such originations continues to be driven by excess cash "chasing" yield (as reflected by the narrowing of original issue discounts in such loans), the reemergence of "covenant lite" transactions and pent-up demand by both investors and issuers. 


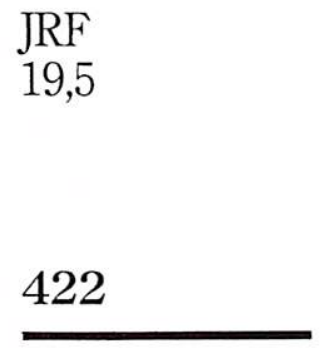

Figure 5.

New-issue loan volume - by year

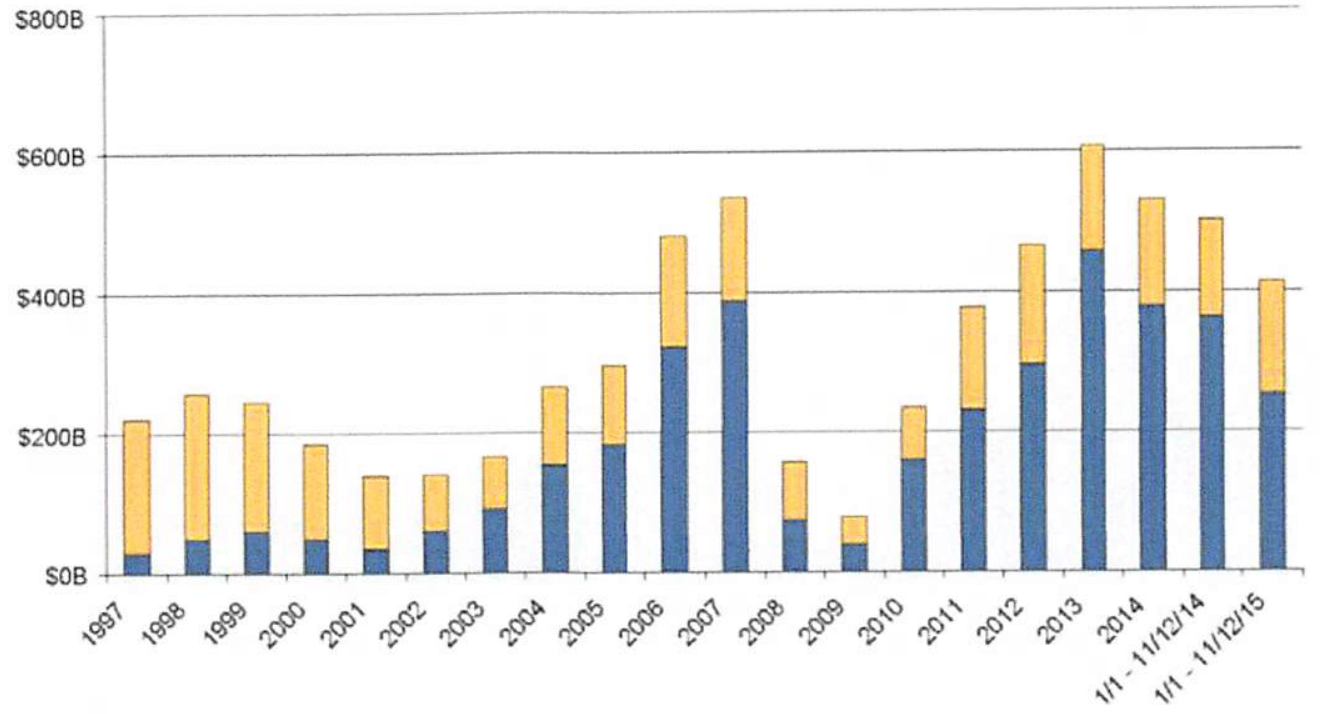

a nstitutional $\square$ Pro Rata

Notes: Excludes existing tranches of add-ons and amendments and restatements with no new money. These numbers comprise loans US dollar denominated in and are subject to revision as Standard and Poor's LCD collects additional data

Source: LCD, an offering of S\&P Global Market Intelligence (2015)

It is also clear from the Shared National Credit Program 2015 Review (joint paper from the Federal Reserve, Federal Deposit Insurance Corporation [FDIC] and Office of the Comptroller of the Currency) that the leveraged loan market is being significantly impacted by non-bank lenders,

Nonbank entities continued to be the primary buyers of riskier leveraged loans. Nonbank entities held a disproportionate share of classified commitments compared with their overall ownership of the SNC (Share National Credit) portfolio (2015, p. 3).

"Classified" credits were defined in this context as assets rated "substandard, doubtful or loss" (2015, p. 3).

Figure 6 illustrates the availability of credit to middle market companies based on earnings before interest, taxes, depreciation and amortization (EBITDA). This figure reflects the decline in lending to the middle market owing to the 2007-2008 financial crisis, as well as the recovery commencing in 2010 . However, despite a lending recovery, the availability of credit to those middle market companies with EBITDA of less than $\$ 200 \mathrm{~m}$ remains quite weak and elusive compared with the years 2000-2007.

Figure 7 shows the sustaining contribution of non-bank intermediaries in providing credit to middle market companies. Without the contribution of such intermediaries, middle market companies would not be able to access capital for expansion and working capital.

Table II below shows the clearing yields for leveraged loans by deal size and EBITDA. Middle market companies continue to pay a "penalty" for credit, especially as compared with subprime commercial borrowers. 


\subsection{Leverage risks in SCM}

Leverage risk in the SCM as it currently stands needs to be understood on its own terms, given the unique nature of the sector and many of the mid-sized borrowers in it. Although the sector has grown significantly since the crisis, leverage levels are not yet considered a systemic concern by most market analysts or regulators. A mature shadow lender (e.g. OneMain [MAIN]) can function at debt to equity levels of 9:1, but most of the smaller midmarket players usually function at no more than between $3: 1$ and 5:1 leverage.

Smaller lenders in the sectors find it hard to obtain senior warehouse lines in today's market that allows them to lever beyond that level until they reach larger critical mass. These leverage ratio restrictions are typically built into the covenants of the warehouse lines themselves. That said, higher levels of leverage are sometimes implicitly achieved by smaller lenders by filling
Shadow credit in the middle market

Figure 6. Middle market new issue loan volume based on EBITDA

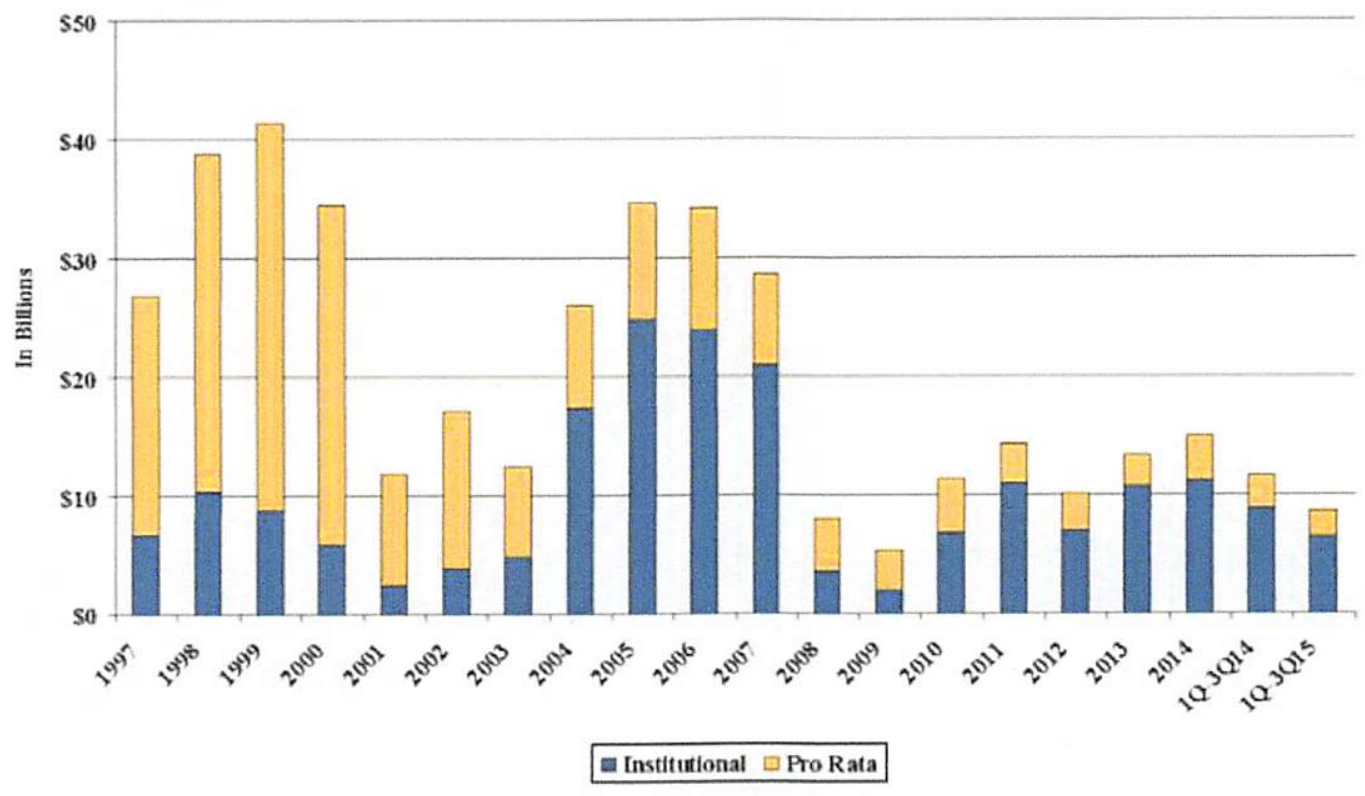

Notes: Institutions are loans bought by asset managers and investors. Pro rata are the loans issued or bought by banks or brokers. The LCD overall volume is based on bank debt size Source: LCD, an offering of S\&P Global Market Intelligence (2015)

Figure 7. Middle market volume by year defined as issuers with EBITDA of $\$ 50 \mathrm{~m}$ or less 
$\mathrm{JRF}$
19,5

424

the denominator in the restrictive covenants with not just equity but also redeemable preferred stock or, in some cases, mezzanine debt (to avoid equity dilution). This can be a quite expensive debt and can be considered implicit incremental leverage. However, as long as it is junior to the warehouse line, the senior lender is (usually) indifferent as to the form of the financial structure of that denominator. Although this is not the norm among prudent shadow lenders, this latter leverage structure, while avoiding equity dilution, can sometimes be destabilizing. If refinancing options are not available or the shadow lender is not generating enough cash to finance the senior and sub-debt, liquidity challenges can arise.

Regulators have so far expressed limited concern about leverage levels in the SCM, particularly those shadow lenders providing credit to commercial borrowers. The Consumer Financial Protection Bureau (CFPB) (discussed later under Section 7) does, however, monitor these issues when it comes to shadow lenders providing credit to consumers. In this case, the CFPB's level of concern on leverage is related to the type of asset (i.e. loan) that the lender is originating. For example, short-term pay-day lending is generally heavily monitored and regulated by the $\mathrm{CFPB}$, and the $\mathrm{CFPB}$ will put stronger restrictions on the leverage of payday lenders. However, shadow lenders providing longer-term installment credit or leases are considered more stable and tend to obtain greater flexibility on leverage levels. In general, the role of the CSFB, although created by Dodd-Frank some years ago, is only just now emerging. It will be an important issue for the SCM to understand the extent of defined powers of the CSFB as they mature over the next few years.

\section{Nature of shadow credit innovation}

So what is really driving the SBS growth outlined in Section 2? As has been postulated and shown, regulatory arbitrage is often a great driver of innovation in finance, and we have seen the influence of regulatory arbitrage increasingly in the post crisis SBS. Knoll (2004, p. 49) stated, "There is a strong incentive to innovate around prohibited or disadvantaged transactions. Such innovations are commonly referred to as regulatory arbitrage." Since the 2007-2008 credit crisis, we have seen innovation in the capital markets, and in particular in the shadow banking sector, driven by a desire by innovative financiers to work around or "arbitrage" the excess regulatory burden on the depositary institutions. Some of these regulatory burdens are just the sheer volume of rules and paperwork imposed on depositaries that wish to lend to areas outside of the most conventional forms of conforming, prime mortgages. But, interestingly, it is not only simple regulatory arbitrage at work. The arbitrage often involves specific forms of capital constraints imposed on the depositary institutions since the credit crisis.

\begin{tabular}{lccc}
\hline New-issue clearing yields & November 2014 (\%) & October 2015 (\%) & November 2015 (\%) \\
\hline By deal size & & & \\
$\$ 200 \mathrm{~m}$ or less & 6.84 & 6.53 & 7.78 \\
$\$ 201 \mathrm{~m}-\$ 50 \mathrm{~m}$ & 6.24 & 6.13 & 6.81 \\
$\$ 351 \mathrm{~m}-\$ 500 \mathrm{~m}$ & 6.37 & 6.52 & 6.85 \\
$\$ 501 \mathrm{~m}$ and over & 5.51 & 5.24 & 5.42 \\
By EBITDA & & & \\
Middle market (\$50m or less) & 6.42 & 6.36 & 6.59 \\
Large corporate (more than $\$ 50 \mathrm{~m})$ & 5.84 & 5.55 & 5.81 \\
Large corporate single-B (more than $\$ 50 \mathrm{~m})$ & 6.08 & 5.85 & 6.13 \\
Source: LCD, an offering of S\&P Global Market Intelligence (2015) & & \\
\end{tabular}


In general, Tier-1 risk-weighted ratios have increased from about 7 per cent across the US banking system to 10 per cent since the credit crisis. Tier-1 leverage (i.e. Tier-1 capital to total, non-risk weighted, assets) has also become much more important in the post-crisis Basel system. Generally, Tier-1 leverage ratios are averaging about 12 per cent+ now across the US banking system. The Basel Accords do not technically require such high levels of capitalization, but individual regional US Federal Reserve Banks impose higher capital standards on banks in the USA depending on the particular credit characteristics of the specific bank.

In addition, the "FDIC" and the Federal Reserve have been periodically asking for incremental capital from a bank if such a bank wishes to lend into slightly higher risk areas (e.g. middle market commercial lending, as opposed to prime, conforming mortgages). So, although many depositary institutions in the USA have been starved of yield in this low-interest-rate environment, the logic to move into slightly higher-risk middle market lending is often thwarted by higher capital standards. Simply stated, increasing a bank's return on equity by lending into the middle market at a higher return is made infeasible if such lending is accompanied by a regulator's required increase in its equity capital in connection with such lending.

It is, in other words, regulatory burdens/capital arbitrage, and the continuing significant demand for capital by middle market entities that the shadow (non-bank) lenders are exploiting by actively lending in the middle market - i.e. taking a lion's share of the credit lending in the USA, which the depositaries are unable to capture under regulatory constraints at this juncture.

\section{Recent case studies}

We consider now some additional examples of the very latest financial models that have been empirically observed in the middle market shadow credit area. These examples complement those shown in our previous research on the SBS in the USA (Zabala and Josse, 2014).

\subsection{Case 1}

We start with a relatively conventional piece of subordinated debt or mezzanine note (effectively privately placed high yield) that can be used to support, for example, a lessor's or asset-based business's ability to source larger warehouse lines and hence grow their business (Table III).

Numerous mid-sized equipment finance companies are funded via senior warehouse lines. These typically contain covenant-heavy provisions that limit the leverage of the borrower (e.g. 5:1 debt to equity ratio). As lessors grow and add more assets, these restrictive covenants can act as a constraint on further expansion by the lessor. After reaching a 5:1 leverage level, growth using the existing warehouse lines can only be achieved by raising new equity. This is an often-unattractive option, as equity is both expensive and results in dilution to earnings per share and ownership.

The private credit markets have been able to play a positive role in solving this issue. Effectively, the lessor issues a mezzanine note, subordinated to the lessor's senior warehouse

\footnotetext{
Issuer type Equipment lessor

Description of situation Mid-sized equipment lessor. Privately placed mezzanine paper (c $\$ 30 \mathrm{~m})$, second lien against equipment after main bank line

Date 2014

Specific issues

Mezzanine capital; bank facility covenants; avoidance of equity dilution

Source: Stern Agee CRT
}

Table III.

Mezzanine debt instrument
Shadow credit in the middle market

425 
JRF facility, but senior to the lessor's equity. The mezzanine note, being junior to the warehouse 19,5 line, can often be treated as equity for the purpose of leverage covenants embedded in the warehouse line. That is, the mezzanine capital "adds" to the " 1 " in the 5:1 leverage ratio. Having increased the denominator in the ratio, the lessor now has renewed capacity to draw further on its warehouse lines and increase assets. Meanwhile, the structure has avoided dilution for the common stock owners. The mezzanine note is effectively acting as quasi (and cheap) equity, typically priced at a 10 per cent+ coupon. This cost is certainly low relative to the notional cost of equity of a small/mid-sized lessor. The lessor must have sufficient cash flow to service the fixed coupon on the mezzanine note (unless some of the mezzanine coupon can be deferred in a pay-in-kind format).

A typical term sheet for this type of transaction may look something as presented in Table IV.

Although many depositary institutions find this type of funding to be outside their constrained lending parameters, it provides important structured funding to private midsized asset-based businesses.

\subsection{Case 2}

Again, we will look at a mezzanine financing. This is a traditional privately placed highyield (cash flow lending) debt, which continues to play an important role for various midsized companies, in this case a wealth manager (Table V).

Traditional private unsecured mezzanine paper continues to play a role in the SCM. This type of paper will typically be used to finance the working capital needs of companies in various sectors where the borrower is showing adequate cash flow to service the paper. This is, effectively, unsecured cash flow financing and provides the owner with an alternative to equity dilution. The financing is recourse to the issuer and transactions in the private markets can be unrated. However, larger transactions typically look for ratings to minimize the cost of the debt and to achieve public market liquidity. We experienced this type of transaction in 2012 to support the working capital needs of an established wealth manager with terms akin to Table VI.

Issuer
Amount
Security type
Collateral
Hair cut
Coupon
Tenure
Underlying leases
Bank consents

Table IV. Investors Mezzanine debt term sheet
Asset lessor

$\$ 20 \mathrm{~m}$

Mezzanine or subordinated note, recourse to asset lessor

Second lien on all leased assets (after the warehouse lender's first lien) Sufficient collateral coverage (post haircut for the warehouse line) to provide meaningful residual collateral for the second lien position $10 \%+$ (depending on haircut and underlying collateral pool), payable quarterly; some interest accrual may be possible in early years (with a possible "look back" payment to increase investor internal rate of return) Three to five years, matching the tenure of relevant leased asset pool (and taking into account the terms of the warehouse lines, i.e. no structural subordination)

Triple net lease Consent by senior warehouse lender(s) to allow mezzanine note to be treated as "quasi equity" for purposes of the issuer's maximum leverage ratio

Credit hedge funds, alternative investment pools at insurers/pension funds, business development companies (BDCs), some banks 
In this instance, we see the importance of the traditional non-bank mid-market-style high-yield product, both in public and private format. It is a very deep market today and critical to many developing businesses underserved by the depositaries.

\subsection{Case 3}

Below, we introduce a slightly more aggressive non-bank product - effectively, short-term commercial mortgage bridge financing. The real focus with respect to these products is the low loan-to-value (LTV), with a much-reduced reliance on whether the borrower has the cash flow to service the debt (Table VII).

Many mid-sized commercial real estate owners/developers find themselves locked out of the mainstream commercial mortgage market, often for no substantive economic rationale. Factors may include the following:

- The prospective borrower may not quite match the credit or loan size standards of mainstream bank lenders.

\begin{tabular}{|c|c|}
\hline Issuer type & Private wealth manager \\
\hline $\begin{array}{l}\text { Description of } \\
\text { situation }\end{array}$ & $\begin{array}{l}\text { Private placement of a thin slice of mezzanine capital to supplement } \\
\text { existing equity capital. Unsecured note }(c \$ 15 \mathrm{~m}) \text { with recourse to the wealth } \\
\text { manager }\end{array}$ \\
\hline Date & 2012 \\
\hline \multicolumn{2}{|l|}{ Specific issues } \\
\hline \multicolumn{2}{|c|}{ Unsecured (non-bank) borrowing; mezzanine format } \\
\hline
\end{tabular}

Shadow credit in the middle market

Table V.

Mezzanine debt for wealth manager

\begin{tabular}{ll}
\hline Issuer & Five-year-old profitable wealth manager \\
Use of proceeds & Working capital \\
Amount & $\$ 15 \mathrm{~m}$ \\
Security & Unsecured subordinated note \\
Coupon & $10 \%-15 \%$, some period of interest accrual possible \\
Tenure & Five years, non-callable two years (then callable at 103,103, 101 annually) \\
& Non-amortizing or amortizing over a 20-year schedule with a bullet at five-year term \\
Interest coverage & \\
Max debt/ equity & - \\
Investors & Credit hedge funds, alternative investment buckets at insurers/pension funds, BDCs
\end{tabular}

Source: Stern Agee CRT
Table VI.

Wealth manager mezzanine debt term sheet

\author{
Issuer type Commercial real estate owner/developer \\ Description of Short-term bridge financing for commercial real estate developers, collateralized against \\ situation real estate lease portfolio or an individual real estate project \\ Date 2014 \\ Specific issues \\ To bridge short-term funding requirements, non-bank commercial mortgages
}

Source: Stern Agee CRT
Table VII. Short-term commercial mortgage bridge financing 
JRF
19,5

428

Table VIII.

Commercial

mortgage note term

sheet
- There may be structural complexity in the entity's business or the specific transaction.

- The underlying commercial real estate may not exactly match the underwriting parameters of conventional lenders (e.g., sub-5 condominium developments, or "due to location").

In addition, there may be a construction and/or development funding element required by the borrower, and many mainstream banks do not accept construction/development risk.

An established private credit market now exists for short-term (six months to two years) commercial real estate funding to provide mid-market real estate developers/ owners the capital to bridge finance until more permanent solutions are found. This is in fact one of the most liquid and active private credit markets currently available in the USA, reflecting the general attractiveness of the commercial real estate market in the USA. Pricing on these transactions is naturally more expensive than bank financing. Higher default levels inevitably also mean that such bridge lenders require tougher collateral packages than mainstream commercial mortgage lenders. Investors tend to be specialist real estate lending groups often backed by groups of high-net-worth investors.

Typical terms on a mid-market commercial real estate (private) bridge financing may be as in Table VIII.

Given the risk profiles of these types of transactions and their short duration, this type of financing is certainly not a typical bank product. Nevertheless, it is critical to many midmarket real estate companies and a key part of the shadow real estate lending landscape.

\subsection{Case 4}

The following case is effectively private (shadow or wholesale) sub-debt funding for the banking market itself (Tier-2 preference stock or debt), but from non-bank sources. It represents a viable product both in public and private format, albeit sourced from specialty investors (Table IX).

Here is another interesting case, in which a depositary institution is not lending into the middle market, but rather a middle market bank is managing to find workable (non-

\begin{tabular}{|c|c|}
\hline Issuer & CRE developer/owner \\
\hline Security type & Commercial mortgage note \\
\hline Tenure & Six months to two years \\
\hline Collateral & First lien on subject property \\
\hline Max LTV & $50 \%-65 \%$ \\
\hline $\begin{array}{l}\text { Interest coverage } \\
\text { (min) }\end{array}$ & $1.25 \mathrm{x}$ \\
\hline Form of collateral & $\begin{array}{l}\text { Lender call on deed to subject property or (even) conditional transfer of title to lender } \\
\text { at closing of loan, as bridge lenders often do not wish to rely on traditional, lengthy } \\
\text { court-based foreclosure processes }\end{array}$ \\
\hline Coupon & $12 \%+2$ points (varies) \\
\hline Amortization & Non-amortizing \\
\hline Default interest & $\begin{array}{l}\text { Some structures can have high levels of default interest }(20 \%+) \text { that accrues and is } \\
\text { usually collected either by borrowers, making the loan (including accrued interest) } \\
\text { whole or on foreclosure }\end{array}$ \\
\hline Investors & Special real estate credit pools, high net worth/accredited investors \\
\hline
\end{tabular}

Source: Stern Agee CRT 
depositary) debt/preferred funding for itself from middle market credit lenders. In our earlier paper, we highlighted an example of a bank Tier-1 private preferred security offering. Although this product continues to be a viable funding option for small and medium-sized banks, we also highlighted the challenges to this product since the demise of the trust preferred securities market. With Tier-1 qualifying preference stock needing to be both noncumulative and genuinely perpetual, this has created a material challenge for investors in the product. Given that these are non-public preferred offerings, and given the perpetual format, investors have very few realistic exit or liquidity options. Tier-1 private preferred offerings are still happening (and structural solutions under current Basel guidelines are being researched); however, this market has been constrained post-credit crisis for this reason.

By contrast, banks have much greater flexibility in the private markets for Tier-2 qualifying preferred securities or subordinated debt. These instruments do not receive equity treatment, but they are not constrained by Tier-1 qualification parameters -i.e. Tier-2 preferred securities can be puttable or redeemable. However, Tier-2 debt can represent (expensive) funding for many banks (particularly those with deep deposit bases or easy access to Federal Home Loan Bank funds). Issuing Tier-2 private subordinated debt or preferred securities, therefore, tends to be an option for banks that are migrating from community bank status to more regional (albeit non-public) operators ( $\$ 3 \mathrm{bn}+$ of assets). In these cases, some stable, well-capitalized banks can find loan growth is exceeding deposit funding capacity and having subordinated debt, while expensive, can profitably add to their growing funding mix/options.

Typical terms might include those presented in Table X.

Regulators are focused both on total and Tier-1 capital ratios today, and so, it is important for private banks to have access to Tier-2 preference/debt capital. In these instances, this product (provided by non-bank investors) can be critically useful. $\begin{array}{ll}\text { Client type } & \text { Regional bank } \\ \text { Description of } & \text { Tier-2 qualifying preference stock. Has attributes of debt capital and provides }\end{array}$ situation incremental debt funding, while contributing to bank's Tier-2 and total capital ratios Date 2014

Specific issues

Tier 2 and total capital; subordinated debt; non-deposit funding for banks

Source: Stern Agee CRT

\section{Shadow credit in the middle market}

429

\section{$=$}


JRF

19,5

430
In summary, the cases discussed earlier illustrate an evolutionary trend of innovation in lending practices in which depositary institutions are not generally participating as lenders. Many of these structures are commonsense, rather than the overly complex innovative structures that we saw leading up to the 2007/2008 financial crisis. Indeed, these evolutionary structures are basically filling a gap in the credit market, as opposed to constituting the creation of fundamentally new products and securities. This raises the question of whether too much of this gap is now being filled by the non-bank lenders specifically because the regulatory regime for depositary institutions has resulted in overly conservative underwriting criteria rather than prudent lending practices.

\section{The aftermath of the post-crisis private, shadow banking sector}

Various issues in shadow banking pre-2007 have been addressed by post-crisis regulation as well as greater market discipline. Collateralized debt obligations ("CDOs") today have been greatly simplified with better quality and without overly complex cohorts of underlying collateral, the credit rating agencies are no longer "in the pocket" of the issuers/originators, and tranching structures of new issues have been simplified. Likewise, the issue of counterparty failure with credit default swaps ("CDS"), as we saw in the AIG case, is being addressed by establishing centralized clearing organizations for all CDS products. These events were forewarned (Partnoy, 2009, 2003/2009; Skeel and Partnoy, 2007).

These developments have largely applied to the now public and well-established CDO and CDS markets, where there is considerable transparency. However, we have demonstrated in Section 3 above new examples of mid-cap "shadow credit" expansion techniques, as a result of the fact that US depositary institutions are not providing, for various reasons discussed above, the credit availability that the middle market needs. In fact, there is evidence that the search for yield in a low-interest-rate environment is leading some US depositary institutions to consider acquiring independent shadow lenders. As described above, they can seriously consider this strategy when they can get permission from their regulators to do so (which is not easy). Often such permission comes with demands for increased regulatory capital, and other types of restrictions, at the acquiring bank (hence in part undermining the bank's rationale for/benefits of moving into more aggressive, higher-yielding $\mathrm{SCMs}$ ).

Although the above-described developments are positive, they are also dangerous. As we have seen and experienced, we are all guinea pigs to a certain extent in new financial innovation in the SBS. The extension and expansion of financial instruments, as well as evolutionary development of such instruments, are needed to get credit to where it is required in the underserved middle market, but such developments may bring some new (as yet unforeseen) shocks to the system. In particular, many speculators are expecting some disturbance to emerge in the financial markets sooner or later, which could ripple through the SCM, any of which could seriously impact wholesale lenders to the SCM. Some such lenders could pull their lines, triggering a credit contraction in the SCM. Whether this would result in severe systemic effects is yet to be seen, and depends on the size the SCM has reached at the date of said potential event.

\section{Regulatory initiatives and concerns}

The important role of regulatory oversight has been discussed in many places (Mayntz, 2012; Zabala, 2013; Zabala and Josse, 2014; Kastner, 2016). See Barth and Miller (2017) for an excellent analysis of bank regulation, capital adequacy standards and the Basel 
Capital Accords. Barth and Wihlborg (2017) discussed the importance of separating traditional investment banking from commercial banking as well as other organizational restrictions to reduce complexity and increase transparency. The FSB has adopted a two-pronged strategy to deal with SBS risk. First, it has created a system-wide monitoring framework to track developments in the SBS with a view to identifying the build-up of systemic risks and initiating corrective actions. Second, the FSB is coordinating and contributing to the development of policy measures in five areas where oversight and regulation may be required to reduce the excessive build-up of leverage, as well as maturity and liquidity mismatching: mitigating risks in banks' interactions with shadow banking entities, reducing the susceptibility of MMFs to "runs" (Cipriani et al., 2013), improving transparency and aligning incentives in securitization, dampening pro-cyclicality and other financial stability risks in securities financing transactions such as repurchase agreements and securities lending and assessing and mitigating financial stability risks posed by shadow banking entities and activities.

The FSB (2014, p. 12) reported that emerging market jurisdictions showed the most rapid increases in OFI. Eight emerging market jurisdictions had 2013 growth rates above 13 per cent (Argentina, China, Turkey, South Africa, India, Russia, Saudi Arabia and Mexico). However, this rapid growth is generally from a relatively small base. Although the non-bank financial system may contribute to a deepening of financial markets in these jurisdictions, careful monitoring is required to detect systemic risk factors (e.g. maturity and liquidity transformation, and leverage) that may develop during periods of rapid expansion of credit provided by the non-bank sector.

There are several proposals under discussion among transnational regulators to address this issue. The FSB's recommendations include establishment of a global monitoring framework, reporting annually, covering 80 per cent of global GDP and 90 per cent of global financial assets; the strengthening of oversight and regulation of shadow banking; the monitoring of global trends and risks in the SBS; development of guidance on the scope of consolidation for prudent bank regulation; and finalization of the application of numerical haircut floors for non-centrally cleared securities financing transactions ("SFTs") to non-bank-to-non-bank transactions. In addition, the clarification of the role of the US CFPB in regulating shadow lenders is necessary, including the exact nature of its powers. Furthermore, a reassessment is required of the burden being imposed on certain depositaries for entering slightly higher-risk middle market commercial lending areas (i.e. banks with strong underwriting track records should not be penalized with either excess regulatory scrutiny or new capital charges for wanting to prudently increase the yield on their assets).

While noting the above prudence considerations for the growing SBS, thought must also be given to the rationale for regulation in the SBS. The SBS is not using depositor (consumer) funds, and most of the investors in this market are sophisticated in nature. As we saw in the case studies above, virtually all the investor types were typically specialist credit funds, BDCs or cohorts of high-net-worth investors (typically "accredited investors" at least). It is not clear that this group of investors need or want the type of protection that conventional depositary institutions must have.

Regulation is a complex issue requiring further research, particularly as to potential systemic risks from an overly inflated SBS. For example, some of the warehouse lenders in the SBS are mainstream depositary institutions, and in the event of a wholesale run in the SBS, these depositary institutions could face mounting defaults on those warehouse lines. In addition, the ability to "term out" such lines into the securitization market may decline in the
Shadow credit in the middle market 
$\mathrm{JRF}$

19,5

432 event of an SBS systemic crisis. In these cases, mainstream banks could be negatively affected, with some potentially materially impacted. Second, the SBS may become so large in itself, as a total proportion of US credit, that a crisis of confidence in the SBS could have effects on the broader US economy. It could effectively result in material sources of credit for US mid-market borrowers drying up, and ultimately have an impact on mid-market business growth and stability. But, as noted above, these risks need to be balanced against the fact that most investors in this market are not consumers. In this case, a relatively unconstrained free market for SBS capital should perhaps at least be the starting point for prudent supervision in the SBS.

\section{New horizons for research}

The SCM will require further research into areas examined by Barth and Miller (2017) and Barth and Wihlborg (2017). We are investigating an analytical model that more accurately describes the size and growth patterns of the shadow lending market. The model is based on the central assumption of this paper that as banks become increasingly regulated, they have an increasing disincentive to lend, and, thus, the SCM grows. We are estimating a database of a large numbers of banks that shows how high capital ratios, high liquidity ratios and low nonperforming loan ratios result in constrained lending. Less lending by depository institutions may be self-imposed following shocks in the banking system, or a result of more aggressive bank regulation and higher capital charges imposed on banking activity. Broadly speaking, both factors (self-imposed caution and regulation) depress lending since the 2008 credit crisis and lead to SCM growth to fill the lending demand in the economy. This may be a fruitful line of inquiry for our next paper.

\section{Summary}

This research provides further evidence that regulatory and financial market changes over the past 20-plus years, especially since 2007, have created a significant supply-demand imbalance in the availability of capital for US middle market companies, particularly those with revenues and market capitalizations under $\$ 250 \mathrm{~m}$ (the lower quadrant). A continuous process of expansion, product extension and underwriting criteria in credit products characterizes the development of the SBS. The market has continued its expansion in the past year and a half.

For SBS investors and lenders, the middle market offers the prospect of superior returns. Despite such superior returns, and despite the middle market continuing to grow at a rapid pace internationally, it remains significantly underserved by experienced and capable professionals. We acknowledge that a very profitable opportunity exists in tailoring a wide range of products and services to meet the needs of the middle market. The opportunities will, however, also come with inevitable risks intrinsic to all financial innovations, product extensions and expansions. The size of the SCM is already beginning to reflect these risks. Many of those risks are yet to be fully revealed to the economic community or understood. Some of these risks do not necessarily need the careful management that we see in the depositary sector precisely because most investors in the SBS are sophisticated actors.

This paper extends our previous work on the SCM to 2015 with analysis and additional cases of evolutionary structures that are filling the gap within the shadow lending market in which the depositary institutions are not generally participating. A clear next step for further research is to develop a more refined quantitative model of the relationship of the SCM to depository institutions and the systemic risks of a large and growing SBS and the extent to which those risks do, or do not, need mitigation via 
regulation, given the overwhelming participation in the SBS sector by very sophisticated financial investors and intermediaries, as opposed to individual depositors (albeit such depositors' participation in the sector on an indirect basis via depositary institutions). This also will require data gathering and analysis of BDCs, credit funds and hedge funds.

Note

1. We use the terms shadow banking system and shadow credit market interchangeably for the purposes of this paper.

\section{References}

A.A.K (2016), "The economist explains: How shadow banking works", The Economist (February 1), available at: www.economist.com/node/21689867/print (accessed 20 November 2016).

Adrian, T. and Shin, H.S. (2009), "The shadow banking system: implications for financial regulation", Banque de France Financial Stability Review, Vol. 105 No. 1, pp. 1-10.

Adrian, T., Adam, A., Boesky, H. and Pozsar, Z. (2012), “Shadow banking”, Revue D'Économie Financière, Vol. 105 No. 1, pp. 157-184.

Baber, G. (2013), "Banking and shadow banking: do any shadows remain?", The Company Lawyer, Vol. 36 No. 4, p. 212.

Barth, J.R., Li, T., Shi, W. and Xu, P. (2015), “China's shadow banking sector: beneficial or harmful to economic growth?”, Journal of Financial Economic Policy, Vol. 7 No. 4, pp. 421-445.

Barth, J.R. and Miller, S.M. (2017), A Primer on the Evolution and Complexity of Bank Regulatory Capital Standards, Mercatus Working Paper, Mercatus Center, George Mason University (February), Arlington, VT.

Barth, J.R. and Wihlborg, C. (2017), "Too big to fail: measures, remedies, and consequences", Financial Markets, Institutions and Instruments, Forthcoming.

Bengtsson, E. (2016), "Investment funds, shadow banking and systemic risk", Journal of Financial Regulation and Compliance, Vol. 24 No. 1, pp. 60-73.

Buchanan, B.G. (2015), "Securitization: a financing vehicle for all seasons?", Journal of Business Ethics, Vol. 138 No. 2, pp. 559-577.

Buchanan, B.G. (2016), "The way we live now: financialization and securitization", Research in International Business and Finance, Vol. 38 No. 3, pp. 663-677.

Camp, L.M. and Ponchione, M. (2013), "BDCs and 1940 Act funds: memorandum from Allen and Overy LLP”, Harvard Law School Forum on Corporate Governance and Financial Regulation. Noam Noked co-editor, (April 25), available at: https://corpgov.law.harvard.edu/2013/04/25/bdcs-and1940-act-funds/ (accessed 4 December 2016).

Chernenko, S. and Sunderam, A. (2014), "Frictions in shadow banking: evidence from the lending behavior of money market mutual funds", Review of Financial Studies, Vol. 27 No. 6, pp. 1717-1750 (June).

Cipriani, M., Martin, A. and Parigi, B.M. (2013), "The fragility of an MMF-intermediated financial system”, Liberty Street Economics, Federal Reserve Bank of New York, NY: (December 13), pp. 1-4.

FSB (2014), "Global shadow banking monitoring report 2014", (October 30).

FSB (2015), "Global shadow banking monitoring report 2015”, (November 12).

Gennaioli, N., Shleifer, A. and Vishny, R.W. (2013), "A model of shadow banking”, The Journal of Finance, Vol. 68 No. 4, pp. 1331-1363.

Górnicka, L. (2016), "Banks and shadow banks: competitors or complements?", Journal of Financial Intermediation, Vol. 27 No. 2, pp. 118-131.
Shadow credit in the middle market 
JRF

19,5

434

Gorton, G. (2010), "Regulating the shadow banking system", Brookings Papers on Economic Activity, Vol. 2010 No. 2, pp. 261-298.

Gramlich, E.M. (2007), Subprime Mortgages: America's Latest Boom and Bust, Urban Institute, Washington, DC.

Gramlich, E.M. (2000), "Subprime lending, predatory lending", Remarks by Governor Edward M. Gramlich at the Federal Reserve Bank of Philadelphia, Community and Consumer Affairs Department, Conference on Predatory Lending, Philadelphia, PA, (December 6), available at: www.federalreserve.gov/boarddocs/speeches/2000/20001206.htm (accessed 5 December 2016).

Guillaume, P. (2015), "Shadow banking and bank capital regulation", Review of Financial Studies, Vol. 28 No. 1, pp. 146-175.

Helgadóttir, O. (2016), "Banking upside down: the implicit politics of shadow banking expertise", Review of International Political Economy, pp. 1-26, doi: 10.1080/09692290.2016.1224196, available at: http://dx.doi.org/10.1080/09692290.2016.1224196 (accessed 5 December 2016).

Josse, J.M. (2015), Dinosaur Derivatives and Other Trades, John Wiley and Sons, West Sussex, United Kingdom.

Kastner, L. (2016), The Power of Weak Interests in Financial Reforms: Explaining the Creation of a US Consumer Agency, Maxpo Discussion Paper Series. Max Planck Sciences Po Center on Coping with Instability in Market Societies, Paris, July, Nos 16/1, pp. 1-25.

Kessler, O. and Wilhelm, B. (2013), "Financialization and the three utopias of shadow banking", Competition and Change, Vol. 17 No. 3, pp. 248-264 (August).

Knoll, M. (2004), The Ancient Roots of Modern Financial Innovation; the Early History of Regulatory Arbitrage, University of PA Law School, Philadelphia, Paper 49 (June 8).

Krippner, G.R. (2005), "The financialization of the American company", Socio-Economic Review, Vol. 3 No. 2, pp. 173-208.

Krippner, G.R. (2009), Capitalizing on the Crisis: The Political Origins of the Rise of Finance, Harvard University Press, Cambridge, MA.

Krugman, P.R. (2009), The Return of Depression Economics and the Crisis of 2008, W.W. Norton and Company, New York, NY and London.

LCD, an offering of S\&P Global Market Intelligence (2015).

Li, T. (2014), "Shadow banking in China: expanding scale, evolving structure", Journal of Financial Economic Policy, Vol. 6 No. 3, pp. 198-211.

Li, J., Hsu, S. and Qin, Y. (2014), "Shadow banking in China: institutional risks", China Economic Review, Vol. 31 No. 4, pp. 119-129.

Lu, Y., Guo, H., Kao, E.H. and Fung, H.G. (2014), "Shadow banking and firm financing in China", International Review of Economics and Finance, Vol. 36 No. C, pp. 40-53.

McCulley, P.A. (2007), Teton Reflections: There Is a Mighty Gulf between the Fed's Cup and the Shadow Banking System's Parched Liquidity Lips, Global Central Bank Focus. KS City Federal Reserve Bank, Annual Symposium, Jackson Hole, WY.

Marshall, W.C. (2014), "Inside shadow banking: understanding the doomsday machine", European Journal of Economics and Economic Policies: Intervention, Vol. 11 No. 3, pp. 315-332.

Mayntz, R. (Ed.) (2012), Crisis and Control: Institutional Change in Financial Market Regulation, Vol. 75, Publication Series of the Max Planck Institute for the Study of Societies, Campus Verlag GmbH, Cologne, Germany, Frankfurt a.M.

Moe, T.V. (2015), "Shadow banking", The Journal of Financial Perspectives, Vol. 3 No. 2, pp. 31-42. (2019-8640).

Moreira, A. and Savov, A. (2014), The Macroeconomics of Shadow Banking, Working Paper Series, National Bureau of Economic Research, No. 20335, Boston, MA. 
O'Sullivan, K.P.V. and Kinsella, S. (2012), "Chasing shadows: Europe prepares to regulate shadow banking: editorial", Journal of Banking Regulation, Vol. 13 No. 3, pp. 173-177.

Partnoy, F. (2003), Infectious Greed: How Deceit and Risk Corrupted the Financial Markets, Henry Holt/ Times Books, New York, NY, (2003, reissue Public Affairs, 2009).

Partnoy, F. (2009), F.I.A.S.C.O., Blood in the Water on Wall Street, W.W. Norton and Company, New York, NY. (1997, (reissue W.W. Norton, 2009).

Pozsar, Z., Adrian, T., Ashcraft, A. and Boesky, H. (2010), Shadow Banking, Federal Reserve Bank of New York, NY, Staff Report No. 458.

Roubini, N. and Setser, B. (2004a), The US as a Net Debtor: The Sustainability of the US External Imbalances, Mimeo, Stern School of Business, New York, NY University.

Roubini, N. and Setser, B. (2004b), Bailouts or Bail-Ins: Responding to Financial Crises in Emerging Economies, Peterson Institute for International Economics, Washington, DC.

Shared National Credit Program (2015), "Board of governors of the federal reserve system, federal deposit insurance corporaton, and office of he comptroller of the currency (2015)", Shared National Credit Program 2015 Review, (November), Washington, D.C., available at: www.federalreserve.gov/ newsevents/pressreleases/files/bcreg20151105a1.pdf (accessed 5 December 2016).

Sinha, A., (2013), "Regulation of shadow banking: issues and challenges", Economic Developments in India: Analysis, Reports, Policy Documents, Academic Foundation's Continuing Series, No. 182, pp. 39-61.

Skeel, D.A. and Partnoy, F. (2007), The Promise and Perils of Credit Derivatives, University of Cincinnati Law Review, US A, Vol. 75, pp. 1019-1051.

Stein, J.C. (2010), "Securitization, shadow banking and financial fragility”, Daedalus, Vol. 139 No. 4, pp. 41-51.

Stiglitz, J.E. (2006), Making Globalization Work, W.W. Norton and Company, New York, NY and London.

Stiglitz, J.E. (2010), FREEFALL: America, Free Markets, and the Sinking of the World Economy, W.W. Norton and Company, New York, NY and London.

Streeck, W. (2014), Buying Time: The Delayed Crisis of Democratic Capitalism, Verso Books, London.

Sullivan, P. (2007), Fed Governor Edward M. Gramlich, Washington, DC Post (Thursday, September 6), available at: www.washingtonpost.com/wp-dyn/content/article/2007/09/05/AR2007090502503. html (accessed 5 December 2016).

Sunderam, A. (2015), "Money creation and the shadow banking system", The Review of Financial Studies, Vol. 28 No. 4, p. 939, available at: www.rfs.oxfordjournals.org/ (accessed 18 November 2016).

The Economist (2014), Shadow Banking in China - Credit Paroled, Vol. 410 No. 8872, pp. 61-62, available at: www.economist.com/news/finance-and-economics/21595483-big-default-avertedcredit-paroled (accessed 8February 2017).

The Economist (2006), "In the shadows of debt", available at: www.economist.com/node/7941780 (accessed 8 February 2017).

The Economist (2016a), Shadow Banks: Dark and Stormy, Vol. 419 No. 8988, p. 7, available at: www. economist.com/news/special-report/21697985-repressed-financial-system-has-sprouted-high-riskalternatives-banks-dark-and-stormy (accessed 8February 2017).

The Economist (2016b), "Special report: Finance in China. Capital markets: Risky returns. China is struggling to unleash the power of stocks and bonds", available at: www.economist.com/node/ 2169/984 (accessed 20 November 2016).

The Economist (2016c), "Special report: Finance in China. The way forward: Pain and prosperity. China is following a well-trodden but dangerous path", available at: www.economist.com/node/2169/ 981 (accessed 20 November 2016).

Zabala, C.A. (2013), "A review of crisis and control: institutional change in financial market regulation", by Mayntz, R. (Ed.), Publication Series of the Max Planck Institute for the Study of Societies, Cologne, Vol. 75, Campus Verlag GmbH, Frankfurt a.M, 2012." Acta Sociologica (University of Oslo), Vol. 56 No. 2, May, pp. 189-192.
Shadow credit in the middle market

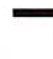

(1)


JRF

19,5

436
Zabala, C.A. and Josse, J.M. (2013), Shadow Banking: Rising Opportunities in the Private Middle Market, KPMG Institutes. New York, NY: KPMG Advisory Institute and Global Enterprise Institute, pp. 1-12.

Zabala, C.A. and Josse, J.M. (2014), "Shadow credit and the private, middle market: pre-crisis and postcrisis developments, data trends and two examples of private, non-bank lending",Journal of Risk Finance, Vol. 15 No. 3, pp. 214-233.

\section{Further reading}

Board of Governors of the Federal Reserve System, Federal Deposit Insurance Corporation, Office of the Comptroller of the Currency (2015), Share National Credits Program 2015 Review, (November), Board of Governors of the Federal Reserve System, Washington, DC.

FSB (2011), "Shadow banking: strengthening oversight and regulation - recommendations of the Financial Stability Board", (October 27).

Krugman, P.R. (2013), End This Depression NOW!, W.W. Norton and Company, New York, NY and London.

Stern Agee CRT (2015), Capital Markets, New York, NY.

Corresponding author

Craig Anthony Zabala can be contacted at: craigzabala@gmail.com

For instructions on how to order reprints of this article, please visit our website: www.emeraldgrouppublishing.com/licensing/reprints.htm Or contact us for further details: permissions@emeraldinsight.com 